\title{
Use of an unmanned aerial vehicle as an alternative to assess the nutritional status of the cotton crop
}

\section{Uso de un vehículo aéreo no tripulado como alternativa para evaluar el estado nutricional del cultivo de algodón}

Uso de veículo aéreo não tripulado como alternativa para avaliação do estado nutricional da cultura do algodão

Jonathan C. Espinoza Delgado ${ }^{1 *}$

Henry A. Pacheco Gil ${ }^{2}$

Rev. Fac. Agron. (LUZ). 2022, 39(1): e223919

ISSN 2477-9407

DOI: https://doi.org/10.47280/RevFacAgron(LUZ).v39.n1.19

\section{Crop Production}

Associate editor: Professor Evelin Perez
${ }^{1}$ Maestría en Ingeniería Agrícola, Instituto de Postgrado, Universidad Técnica de Manabí, Ecuador.

${ }^{2}$ Facultad de Ingeniería Agrícola, Universidad Técnica de Manabí, Ecuador.

Received: 14-04-2021

Accepted: 05-12-2021

Published: 24-02-2022

\section{Keywords:}

EBEE SQ

Sequoia

Chlorophyll Index multispectral

Visible spectrum

\begin{abstract}
The use of unmanned aerial vehicles in photogrammetric studies allows obtaining spatial data in short periods of time and with high spatial resolution. In the research, multispectral images were processed for the study of nutritional conditions of the cotton crop (Gossypium hirsutum). An experimental design of the crop was developed, with different doses and nitrogen sources, in a factorial arrangement with 16 treatments and 4 repetitions in plots completely distributed at random. The EBEE SQ agricultural drone, equipped with the Parrot Sequoia camera, was used and a photogrammetric flight was planned, with the Emoticon AG software, which was synchronized with the drone to establish the flight parameters and capture the reflectance information of the visible spectrum, infrared and red border. The captured images were processed with the PIX4D Mapper software to generate the orthophoto and the 4 spectral bands used in the calculation of the chlorophyll index. Using map algebra tools from ArcGIS software on the results obtained, an analysis of variance was performed with the ANOVA model. With the calculated indices it was possible to show differences in the vigor of the crop depending on the treatments. The analysis of the results showed significant differences in the spectral response of the cotton crop fertilized with different sources (urea, pine nut cake, hen manure and bovine

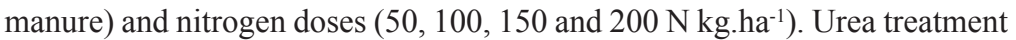
at the 150 dose of $\mathrm{N} \mathrm{kg.ha-1}$ showed the best spectral response.
\end{abstract}




\section{Resumen}

El uso de los vehículos aéreos no tripulados en estudios fotogramétricos permite la obtención de datos espaciales en cortos periodos de tiempo y de alta resolución espacial. En la investigación se procesaron imágenes multiespectrales para el estudio de condiciones nutricionales del cultivo de algodón (Gossypium hirsutum). Se desarrolló un diseño experimental del cultivo, con diferentes dosis y fuentes nitrogenadas, en un arreglo factorial con 16 tratamientos y 4 repeticiones en parcelas distribuidas completamente al azar. Se utilizó el dron agrícola EBEE SQ, equipado con la cámara Parrot Sequoia, y se planificó un vuelo fotogramétrico, con el software Emoticón AG, mismo que se sincronizó con el dron para establecer los parámetros de vuelo y capturar la información de reflectancia del espectro visible, infrarrojo y borde rojo. Las imágenes capturadas se procesaron con el software PIX4D Mapper para generar la ortofoto y las 4 bandas espectrales usadas en el cálculo del índice de clorofila. Utilizando herramientas de algebra de mapas del software ArcGIS sobre los resultados obtenidos, se ejecutó un análisis de varianza con el modelo ANOVA. Con los índices calculados se pudo evidenciar diferencias en la vigorosidad del cultivo en función de los tratamientos. El análisis de los resultados mostró diferencias significativas en la respuesta espectral del cultivo de algodón fertilizado con diferentes fuentes (urea, torta de piñón, gallinaza y estiércol bovino) y dosis nitrogenadas $\left(50,100,150\right.$ y $\left.200 \mathrm{~N} \mathrm{~kg}^{-h^{-1}}\right)$. El tratamiento de urea en la dosis de $150 \mathrm{~N} \mathrm{kg.ha-1}$ mostro la mejor respuesta espectral.

Palabras clave: EBEE SQ, Sequoia, índice de clorofila, multiespectral, espectro visible.

\section{Resumo}

A utilização de veículos aéreos não tripulados em estudos fotogramétricos permite a obtenção de dados espaciais em curtos períodos de tempo e com alta resolução espacial. Na pesquisa, imagens multiespectrais foram processadas para o estudo das condições nutricionais da cultura do algodão (Gossypium hirsutum). Foi desenvolvido um delineamento experimental da cultura, com diferentes doses e fontes de nitrogênio, em arranjo fatorial com 16 tratamentos e 4 repetições em parcelas totalmente distribuídas ao acaso. Foi utilizado o drone agrícola EBEE SQ, equipado com a câmera Parrot Sequoia, e planejado um voo fotogramétrico, com o software Emoticon AG, que foi sincronizado com o drone para estabelecer os parâmetros de voo e capturar as informações de refletância do espectro visível., borda infravermelha e vermelha. As imagens capturadas foram processadas com o software PIX4D Mapper para gerar a ortofoto e as 4 bandas espectrais utilizadas no cálculo do índice de clorofila. Usando ferramentas de álgebra de mapas do software ArcGIS nos resultados obtidos, uma análise de variância foi realizada com o modelo ANOVA. Com os índices calculados foi possível mostrar diferenças no vigor da cultura em função dos tratamentos. A análise dos resultados mostrou diferenças significativas na resposta espectral da cultura do algodão fertilizado com diferentes fontes (uréia, torta de pinhão, esterco de galinha e

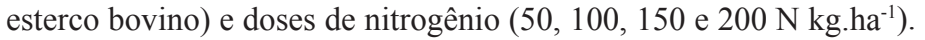

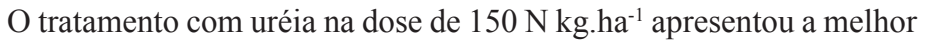
resposta espectral.

Palavras chave: EBEE SQ, Sequoia, número de clorofila, multiespectral, espectro visível.

\section{Introduction}

Remote sensing based on satellites and unmanned aircraft reduces the problem in the scarce implementation of technological alternatives for planning in agriculture. This technology, in response to the various physiological and nutritional problems presented by crops, allows improving the planning of agricultural activities, predicting damage and making appropriate decisions in situations that affect their development (Macías-Duarte et al., 2021).

The images of the unmanned aerial vehicles, equipped with a multispectral camera, capture spectral images that are useful for agricultural purposes in estimating the efficiency of some treatments and their effect on the phenological development of the crop (Burbano and Peñaranda, 2020). The concentration of chlorophyll in the leaf can vary depending on growth stage of the plant and proportional to the amount of nitrogen it has (Ledesma et al., 2020).

The chlorophyll index is applied to estimate the total amount of chlorophyll in plants and is generally calculated from the reflectance in the green, red and red edge bands of the electromagnetic spectrum. These bands respond to slight variations in the amount of chlorophyll and are consistent for most types of plants. The cell structure of plants tends to reflect waves within this spectral range, resulting in more reflected light; therefore, the higher the reflection, the greener the area will be, indicating the level of vigor of the crop, allowing, in turn, to identify the affected areas and respond in a timely manner (Prando et al., 2019).

RGB and multispectral data have been used to estimate the chlorophyll index $(\mathrm{Cl})$, which are based on the random application of nitrogen in crops. With the application of remote sensing techniques and with the support of multispectral images, to analyze the morphological and nutritional conditions that the human eye cannot easily observe, it is intended to support a technified agricultural system. The cameras are managed by geographic information systems and aerial tools, which establish parameters in the crops for their better management (Kharuf-Gutierrez et al., 2018), hence the objective of this research was to process multispectral images for the study of nutritional conditions of cotton cultivation.

\section{Materials and methods}

Location of the study: The study area was the central coastal region of Ecuador, in the experimental campus "La Teodomira" of the Universidad Técnica de Manabí, Santa Ana Canton, Lodana parish, North coordinates 9870040 and East 568460 at 56 m.a.s.l. (figure 1).

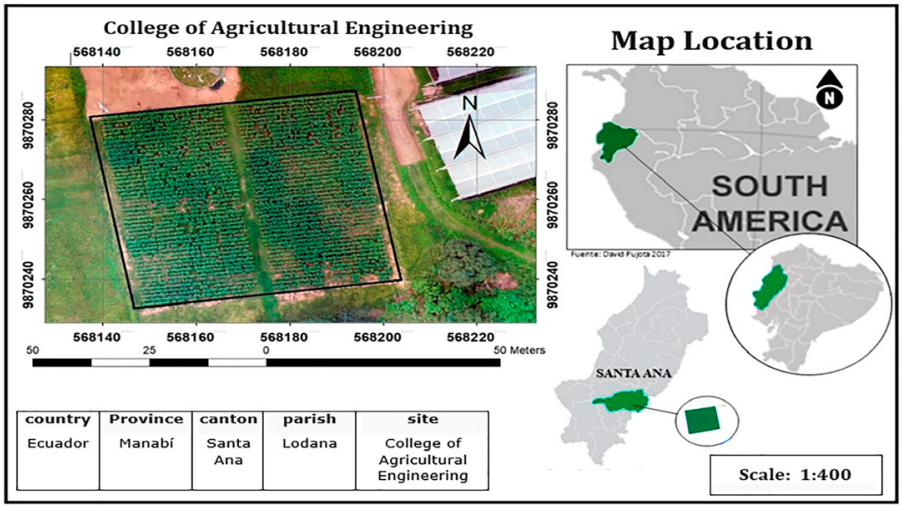

Figure 1. Location of the study área and cotton plots (scientific name) in the experimental campus of the Universidad Técnica de Manabí, Ecuador. 
Vegetal material. Cotton cultivation (Gossypium hirsutum) was evaluated in a total area of $2,688 \mathrm{~m}^{2}$, divided into 64 plots of $6 \mathrm{~m}^{2}$ each, with a $3 \%$ slope. Sowing was carried out at the end of November 2019, with a separation of $1 \mathrm{~m}$ between rows and $0.4 \mathrm{~m}$ between plants, as well as a single plant per planting point.

Flight plan. The photogrammetric flight was programmed through the "EMOTION AG" software, considering the parameters detailed in table 1 and figure 2 .

Table 1. Parameters established by the "EMOTION AG" software applied in the execution of the flight plan.

\begin{tabular}{ll}
\hline Information & Emotion AG \\
\hline Camera & RGB (16 Mpx) + Multispectral (1.2 Mpx) \\
Type & Sequoia 1.7.1 \\
Image size (cm/pixel) & $11.00 \mathrm{~cm} \cdot \mathrm{px}^{-1}$ \\
Flight time (s) & $15: 47 \mathrm{~min}$ \\
Flight area & $24.2 \mathrm{ha}$ \\
$\begin{array}{l}\text { Longitudinal overlap } \\
\text { (\%) }\end{array}$ & $80 \%$ \\
Transverse overlap (\%) & $70 \%$ \\
Flight height (m) & $150 \mathrm{~m}$ \\
Flight speed (m.s $\left.\mathrm{s}^{-1}\right)$ & $4 \mathrm{~m} . \mathrm{seg}^{-1}$ \\
\hline
\end{tabular}

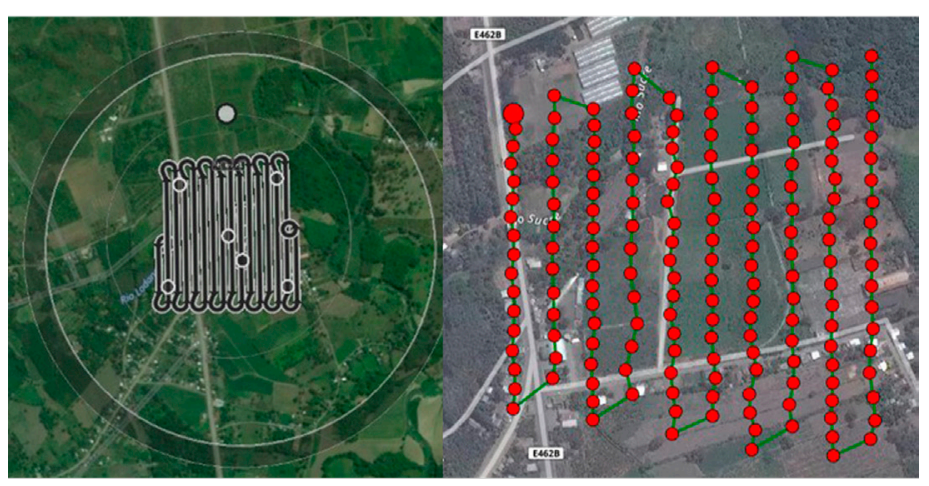

Figure 2. Flight planning in the study area.

Capture and processing of multispectral images. The photogrammetric mission was carried out with the EBEE SQ unmanned aerial vehicle, instrumented with the "Parrot Sequoia" multispectral camera. Three hundred and seventy nine images were captured with a pixel size of $11.00 \mathrm{~cm}$, using the JPEG format for the RBG image and the multispectral bands "GREEN, RED, NIR, EDGE", considering the performance of the geometry and radiometry of multispectral images of the camera (Parrot Drone SAS, 2020). The images from the Parrott Sequoia camera (Pix4D SA., 2019) were processed by the Pix4D photogrammetry program, with which georeferenced 2D and 3D digital models, orthomosaics and highprecision separated spectral bands were created.
Algebraic operations in GIS. With the multispectral bands, and using the equations proposed by Zhou et al. (2019), four chlorophyll indices were calculated (table 2), through the map algebra tools of the Arc GIS software called "raster calculator", which allows mathematical operations to be performed between the files, generating a file with the values of the indices for each pixel of the image (ArcGIS, 2020) that contains the sampling of 20 points in each treatment; for this, a polygon-type vector Shape layer was created with which the analysis areas of each of the areas where the treatments were applied were delimited, according to the experimental design. Once the limits of each treatment on the chlorophyll indices were established, a pointtype vectorial shape was created.

The value of the indices were obtained for each point, using the ArcGIS Spatial Analyst Extract Multi Values to Points tool, which extracts cell values at specified locations in a point feature class from one or more rasters and records the values in the attribute table of the point feature class (ArcGis. 2020), in order to obtain a reliable value of each treatment (Marín et al., 2018). Finally, the table of attributes of the vector shape layer of the point type was extracted, where the maximum and minimum values were obtained, exported as an .xlsx format file that was executed with the Excel program, showing all the points with their values on each chlorophyll index for analysis of variance.

Table 2. Chlorophyll indices used for the evaluation of cotton cultivation in the study area.

\begin{tabular}{cc}
\hline Index & Formula \\
\hline "Simple Relationship Red Border" & (Red Border) / (Red) \\
"Red Simple Proportion" & (Near Infrared) / (Red) \\
"Reflectance Spectra Ratio Analysis & (Red Border) / (Green) \\
(RARSc)" & (Red Border - Red) / (Red \\
Index (NDRE)" & Border + Red) \\
\hline
\end{tabular}

Source: Zhou et al. (2019).

From the division of zones, a new layer in .shp format of polygon type was generated using ArcGIS tools, which allowed creating the delimitations of the new plots based on the experimental design.

Each formula was used independently, differentiating each treatment according to the experimental design proposed and implemented in the ArcGIS software, using the polygons. Each operation applied in the crop presents different minimum and maximum levels of reflectance, these being undefined by the different bands and radios used, do not have an established minimum and maximum limit, so it is estimated that the higher the maximum levels, the higher the chlorophyll index and vice versa.

Subsequently, the ArcGIS "zonal statistics" tool was applied to generate statistics of the chlorophyll indices in each of the plots (Bartesaghi et al., 2018).

Design and statistical analysis. The design was in completely randomized blocks, with a $4 * 4$ factorial arrangement, differentiated in sources and fertilization doses, as shown in table 3 . Four nitrogenous sources were used (bovine manure, hen manure, pine nut cake and urea) and four doses $\left(50,100,150,200 \mathrm{~N} \mathrm{~kg}^{-h^{-1}}\right)$, for a total of 16 fertilization treatments. 
4-7| Rev. Fac. Agron. (LUZ). 2022, 39(1): e223919. January - March. ISSN 2477-9407.

Table 3. Doses, sources and estimation of nitrogenous fertilization used in the design of treatments.

\begin{tabular}{lcll}
\hline Treatment & Dose $\left(\mathrm{N} \mathrm{kg} \cdot \mathrm{ha}^{-1}\right)$ & Source & Estimation \\
\hline T1 & 50 & Bovine manure & Very low \\
T2 & 100 & Bovine manure & Short \\
T3 & 150 & Bovine manure & High \\
T4 & 200 & Bovine manure & Very high \\
T5 & 50 & Hen manure & Very low \\
T6 & 100 & Hen manure & Short \\
T7 & 150 & Hen manure & High \\
T8 & 200 & Hen manure & Very high \\
T9 & 50 & Pine nut cake & Very low \\
T10 & 100 & Pine nut cake & Short \\
T11 & 150 & Pine nut cake & High \\
T12 & 200 & Pine nut cake & Very high \\
T13 & 50 & Urea & Very low \\
T14 & 100 & Urea & Short \\
T15 & 150 & Urea & High \\
T16 & 200 & Urea & Very high \\
\hline
\end{tabular}

For the statistical analysis, the Statistical Package for the Social Sciences (SPSS) program was used. The variance analysis of one factor and the Tukey test were performed, which were extracted from $\operatorname{ArcGIS}$ through an Excel table that generated the maximum and minimum limits of each polygonal division of each treatment.

\section{Results and discussion}

Capture of the images. High-quality images were captured to obtain the map with the formulation of the chlorophyll index, the results of which made it possible to highlight the usefulness of the sensor for agricultural use. These results are consistent with the reports of Karydas et al. (2020).

Chlorophyll indices and crop vigor. The colored composition of the indices calculated in figure 3 , showed in green hue, the areas where the vegetation developed better and the amount of chlorophyll was high; yellows and oranges indicated less vigor, while reddish tones represented the soil without vegetation, in the intercrop areas.

In figure 3 it was observed that the plots with maximum vigor of the cotton crop, corresponded to the treatments T15 and T16 (urea

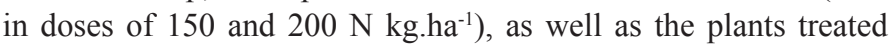
with pine nut cake (T10, T11, T12) at doses of 100, 150 and $200 \mathrm{~N}$ $\mathrm{kg} \cdot \mathrm{ha}^{-1}$ and poultry manure at doses of 150 and $200 \mathrm{~N} \mathrm{kg.ha-}$

Simple red border ratio index. The results obtained for the simple red edge relationship index indicated that there are significant differences in the spectral response of the crop between some treatments (table 4).

As can be seen in able 4, the spectral response of the cotton crop, according to the simple red edge relationship index, does not show significant differences between the different concentrations of bovine manure. Regarding hen manure, differences were only observed in the high dose $\left(200 \mathrm{~N} \mathrm{~kg}^{-} \mathrm{ha}^{-1}\right)$. There were also no differences between bovine manure and the low dose of pine nut cake (50 N kg.ha-1), except for the remaining doses of pine nut

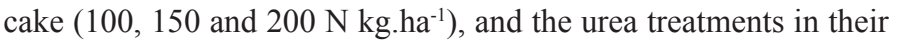
different doses.
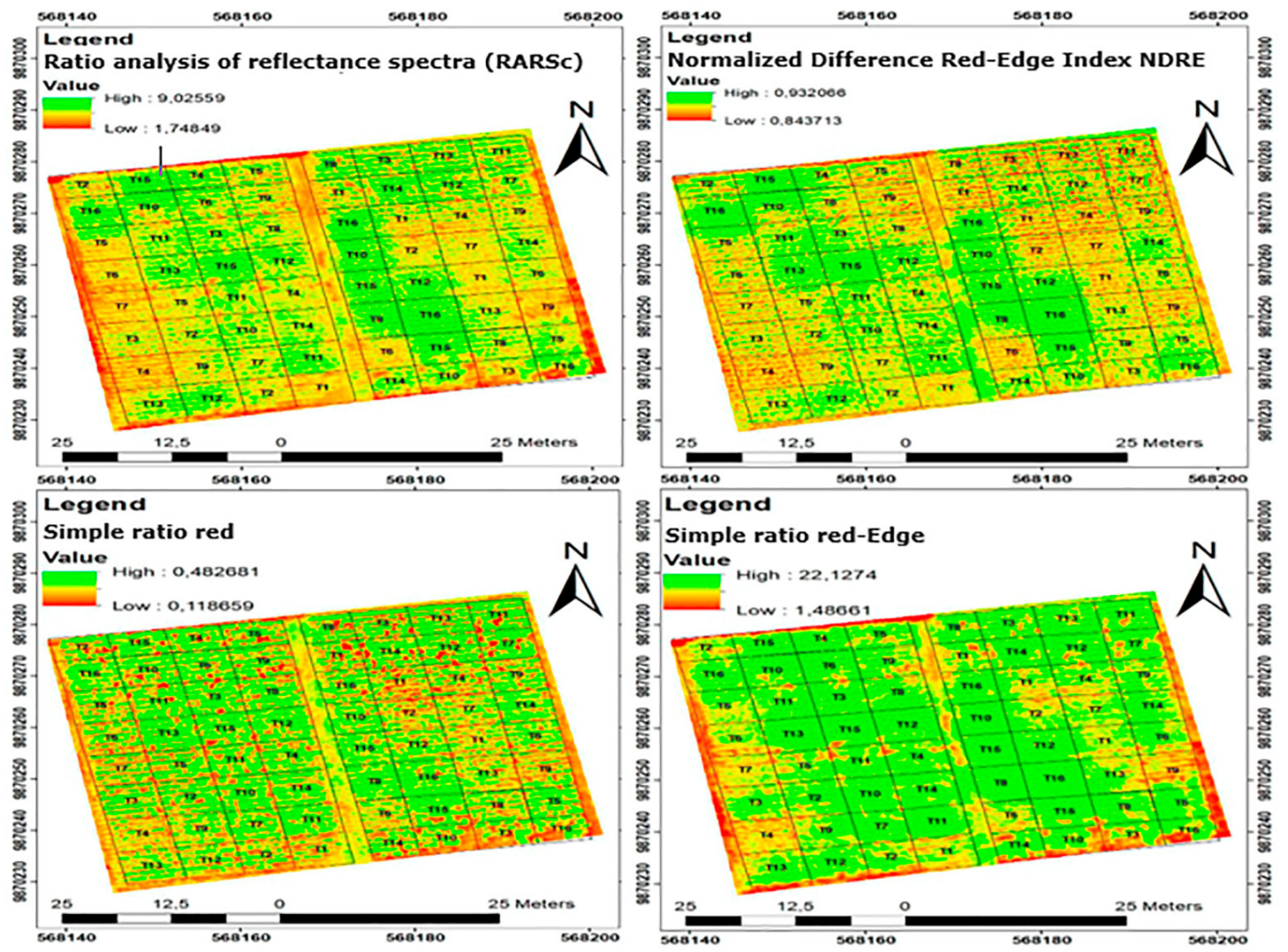

Figure 3. Schematization of the different chlorophyll indices applied. 
The hen manure treatments only showed differences among themselves in the low $\left(50 \mathrm{~N} \mathrm{~kg}^{-h^{-1}}\right)$ and very high $\left(200 \mathrm{~N} \mathrm{~kg}^{-h a^{-1}}\right)$ doses. Likewise, hen manure maintains significant differences only with the high and very high doses of urea (150 and $\left.200 \mathrm{~N} \mathrm{~kg}^{-\mathrm{ha}^{-1}}\right)$. On the other hand, the high and very high doses of hen manure showed significant differences with the pine nut cake and urea treatments. While the high and very high doses of urea (150 and 200 $\mathrm{N} \mathrm{kg} \cdot \mathrm{ha}^{-1}$ ), showed significant differences with bovine manure and hen manure.

The simple red proportion index can be seen in table 5, where the differences are not significant, finding the greatest differences in the bovine manure treatments at their lowest dose $\left(50 \mathrm{~N} \mathrm{~kg} \mathrm{ha}^{-1}\right)$, with respect to hen manure treatments at very high doses $\left(200 \mathrm{~N} \mathrm{~kg}^{-h^{-1}}\right)$, pine nut cake at doses of 150 and $200 \mathrm{~N} \mathrm{kg.ha}{ }^{-1}$ and urea at a medium dose $\left(150 \mathrm{~N} \mathrm{~kg} \mathrm{ha}^{-1}\right)$. It was possible to observe how urea, in doses of $150 \mathrm{~N} \mathrm{~kg} \cdot \mathrm{ha}^{-1}$, presented significant differences, only with the hen manure dose of $200 \mathrm{~N} \mathrm{~kg}$.ha-1. In relation to the source of urea,

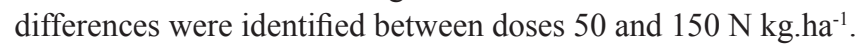

The results of the RARSC reflectance spectra ratio index, shown in table 6 , showed that there are no significant differences between the bovine manure and hen manure treatments, except in the dose of $50 \mathrm{~N} \mathrm{~kg} \cdot \mathrm{ha}^{-1}$. According to the studies carried out by Xu et al. (2019), the RARSC reflectance spectra ratio index contrast representation is optimal for the application of chlorophyll estimation.

Table 4. Significance level of the spectral response according to the "simple red edge relationship" index obtained in cotton plants treated with different nitrogen sources.

\begin{tabular}{|c|c|c|c|c|c|c|c|c|c|c|c|c|c|c|c|c|}
\hline & 1 & 2 & 3 & 4 & 5 & 6 & 7 & 8 & 9 & 10 & 11 & 12 & 13 & 14 & 15 & 16 \\
\hline 1 & & B & B & B & B & B & B & A & B & A & A & A & A & A & A & A \\
\hline 2 & B & & B & B & B & B & B & A & B & A & A & A & B & B & A & A \\
\hline 3 & B & B & & B & B & B & B & A & B & B & A & A & B & B & A & B \\
\hline 4 & B & B & B & & B & B & B & A & B & A & A & A & B & B & A & B \\
\hline 5 & B & B & B & B & & B & B & A & B & B & A & B & B & B & A & B \\
\hline 6 & B & B & B & B & B & & B & A & B & A & A & A & B & A & A & A \\
\hline 7 & B & B & B & B & B & B & & A & B & A & $\mathrm{A}$ & A & B & B & A & B \\
\hline 8 & A & A & A & A & A & A & A & & A & B & B & B & B & B & B & B \\
\hline 9 & B & B & B & B & B & B & B & A & & A & A & A & B & B & A & B \\
\hline 10 & A & A & B & A & B & A & A & B & A & & A & B & B & B & B & B \\
\hline 11 & A & A & A & A & A & A & A & B & A & B & 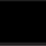 & B & B & B & B & B \\
\hline 12 & A & A & A & A & B & A & A & B & A & B & B & 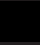 & B & B & B & B \\
\hline 13 & A & B & B & B & B & B & B & B & B & B & B & B & 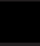 & B & A & B \\
\hline 14 & A & B & B & B & B & A & B & B & B & B & B & B & B & 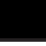 & B & B \\
\hline 15 & A & A & A & A & A & A & A & B & A & B & B & B & A & B & 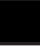 & B \\
\hline 16 & A & A & B & B & B & A & B & B & B & B & B & B & B & B & B & \\
\hline
\end{tabular}

A: Significant difference. B: There is no significant difference.

Table 5. Significance level of the spectral response according to the index of "simple red proportion" obtained in cotton plants treated with different nitrogen sources.

\begin{tabular}{|c|c|c|c|c|c|c|c|c|c|c|c|c|c|c|c|c|}
\hline & 1 & 2 & 3 & 4 & 5 & 6 & 7 & 8 & 9 & 10 & 11 & 12 & 13 & 14 & 15 & 16 \\
\hline 1 & & $B$ & $B$ & $B$ & $B$ & $B$ & $B$ & $A$ & $B$ & $B$ & $A$ & $A$ & $B$ & $B$ & $A$ & $B$ \\
\hline 2 & $B$ & & $B$ & $B$ & $B$ & $B$ & $B$ & $B$ & $B$ & $B$ & $B$ & $B$ & $B$ & $B$ & $A$ & $B$ \\
\hline 3 & $B$ & $B$ & & $B$ & $B$ & $B$ & $B$ & $B$ & $B$ & $B$ & $B$ & $B$ & $B$ & $B$ & $B$ & $B$ \\
\hline 4 & $B$ & $B$ & $B$ & & $B$ & $B$ & $B$ & $B$ & $B$ & $B$ & $B$ & $B$ & $B$ & $B$ & $B$ & $B$ \\
\hline 5 & $B$ & $B$ & $B$ & $B$ & & $B$ & $B$ & $B$ & $B$ & $B$ & $B$ & $B$ & $B$ & $B$ & $B$ & $B$ \\
\hline 6 & $B$ & $B$ & $B$ & $B$ & $B$ & & $B$ & $B$ & $B$ & $B$ & $B$ & $B$ & $B$ & $B$ & $B$ & $B$ \\
\hline 7 & $B$ & $B$ & $B$ & $B$ & $B$ & $B$ & & $A$ & $B$ & $B$ & $B$ & $B$ & $B$ & $B$ & $A$ & $B$ \\
\hline 8 & $A$ & $B$ & $B$ & $B$ & $B$ & $B$ & $A$ & & $B$ & $B$ & $B$ & $B$ & $B$ & $B$ & $B$ & $B$ \\
\hline 9 & $B$ & $B$ & $B$ & $B$ & $B$ & $B$ & $B$ & $B$ & & $B$ & $B$ & $B$ & $B$ & $B$ & $B$ & $B$ \\
\hline 10 & $B$ & $B$ & $B$ & $B$ & $B$ & $B$ & $B$ & $B$ & $B$ & & $B$ & $B$ & $B$ & $B$ & $B$ & $B$ \\
\hline 11 & $A$ & $B$ & $B$ & $B$ & $B$ & $B$ & $B$ & $B$ & $B$ & $B$ & & $B$ & $B$ & $B$ & $B$ & $B$ \\
\hline 12 & $A$ & $B$ & $B$ & $B$ & $B$ & $B$ & $B$ & $B$ & $B$ & $B$ & $B$ & & $B$ & $B$ & $B$ & $B$ \\
\hline 13 & $B$ & $B$ & $B$ & $B$ & $B$ & $B$ & $B$ & $B$ & $B$ & $B$ & $B$ & $B$ & & $B$ & $A$ & $B$ \\
\hline 14 & $B$ & $B$ & $B$ & $B$ & $B$ & $B$ & $B$ & $B$ & $B$ & $B$ & $B$ & $B$ & $B$ & . & $B$ & $B$ \\
\hline 15 & $A$ & $A$ & $B$ & $B$ & $B$ & $B$ & $A$ & $B$ & $B$ & $B$ & $B$ & $B$ & $A$ & $B$ & & $B$ \\
\hline 16 & $B$ & $B$ & $B$ & $B$ & $B$ & $B$ & $B$ & $B$ & $B$ & $B$ & $B$ & $B$ & $B$ & $B$ & $B$ & \\
\hline
\end{tabular}

A: Significant difference. B: There is no significant difference. 
6-7| Rev. Fac. Agron. (LUZ). 2022, 39(1): e223919. January - March. ISSN 2477-9407.

Table 6. Significance level of the spectral response according to the "RARSC reflectance spectra ratio analysis" index, obtained in cotton plants treated with different nitrogen sources.

\begin{tabular}{|c|c|c|c|c|c|c|c|c|c|c|c|c|c|c|c|c|}
\hline & 1 & 2 & 3 & 4 & 5 & 6 & 7 & 8 & 9 & 10 & 11 & 12 & 13 & 14 & 15 & 16 \\
\hline 1 & & $B$ & $B$ & $B$ & $B$ & $B$ & $B$ & $A$ & $B$ & $A$ & $A$ & $A$ & $A$ & $A$ & $A$ & $A$ \\
\hline 2 & $B$ & & $B$ & $B$ & $B$ & $B$ & $B$ & $B$ & $B$ & $B$ & $B$ & $B$ & $B$ & $B$ & $A$ & $A$ \\
\hline 3 & $B$ & $B$ & & $B$ & $B$ & $B$ & $B$ & $A$ & $B$ & $B$ & $B$ & $B$ & $B$ & $B$ & $A$ & $A$ \\
\hline 4 & $B$ & $B$ & $B$ & & $B$ & $B$ & $B$ & $A$ & $B$ & $B$ & $B$ & $A$ & $B$ & $B$ & $A$ & $A$ \\
\hline 5 & $B$ & $B$ & $B$ & $B$ & 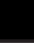 & $B$ & $B$ & $B$ & $B$ & $B$ & $B$ & $B$ & $B$ & $B$ & $A$ & $A$ \\
\hline 6 & $B$ & $B$ & $B$ & $B$ & $B$ & 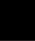 & $B$ & $A$ & $B$ & $A$ & $A$ & $A$ & $A$ & $A$ & $A$ & $A$ \\
\hline 7 & $B$ & $B$ & $B$ & $B$ & $B$ & $B$ & 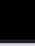 & $A$ & $B$ & $A$ & $A$ & $A$ & $A$ & $A$ & $A$ & $A$ \\
\hline 8 & $A$ & $B$ & $A$ & $A$ & $B$ & $A$ & $A$ & 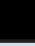 & $A$ & $B$ & $B$ & $B$ & $B$ & $B$ & $B$ & $B$ \\
\hline 9 & $B$ & $B$ & $B$ & $B$ & $B$ & $B$ & $B$ & $A$ & 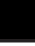 & $B$ & $B$ & $A$ & $B$ & $B$ & $A$ & $A$ \\
\hline 10 & $A$ & $B$ & $B$ & $B$ & $B$ & $A$ & $A$ & $B$ & $B$ & 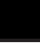 & $B$ & $B$ & $B$ & $B$ & $A$ & $B$ \\
\hline 11 & $A$ & $B$ & $B$ & $B$ & $B$ & $A$ & $A$ & $B$ & $B$ & $B$ & . & $B$ & $B$ & $B$ & $B$ & $B$ \\
\hline 12 & $A$ & $B$ & $B$ & $A$ & $B$ & $A$ & $A$ & $B$ & $A$ & $B$ & $B$ & & $B$ & $B$ & $B$ & $B$ \\
\hline 13 & $A$ & $B$ & $B$ & $B$ & $B$ & $A$ & $A$ & $B$ & $B$ & $B$ & $B$ & $B$ & 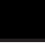 & $B$ & $A$ & $B$ \\
\hline 14 & $A$ & $B$ & $B$ & $B$ & $B$ & $A$ & $A$ & $B$ & $B$ & $B$ & $B$ & $B$ & $B$ & & $A$ & $B$ \\
\hline 15 & $A$ & $A$ & $A$ & $A$ & $A$ & $A$ & $A$ & $B$ & $A$ & $A$ & $B$ & $B$ & $A$ & $A$ & & $B$ \\
\hline 16 & $A$ & $A$ & $A$ & $A$ & $A$ & $A$ & $A$ & $B$ & $A$ & $B$ & $B$ & $B$ & $B$ & $B$ & $B$ & \\
\hline
\end{tabular}

A: Significant difference. B: There is no significant difference.

The results obtained for the hen manure cake in medium doses (100

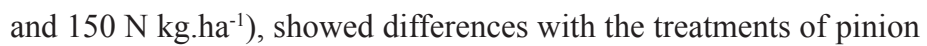

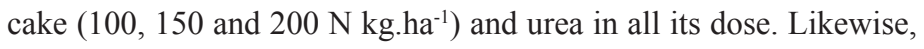
a singularity was observed in the same treatments, especially in the urea source, with which a spectral response was observed where the

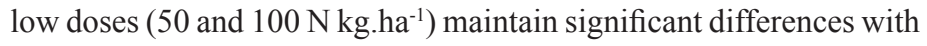
the highest doses. (200 N kg.ha-1). According to similar investigations carried out by Zhou et al. (2017), the RARSC vegetation index yields fairly robust results for this categorization and the estimation of the chlorophyll content of crops.

For its part, the spectral response of the normalized difference red edge index "NDRE" (table 7), reflected that the concentration of bovine manure in its lowest dose presented significant differences with all treatments in their different doses, such as hen

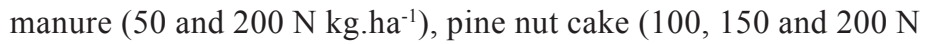
$\left.\mathrm{kg} \cdot \mathrm{ha}^{-1}\right)$ and urea.

Table 7. Significance level of the spectral response according to the "NDRE normalized difference red edge index", obtained in cotton plants treated with different nitrogen sources.

\begin{tabular}{|c|c|c|c|c|c|c|c|c|c|c|c|c|c|c|c|c|}
\cline { 2 - 16 } \multicolumn{1}{c|}{} & 1 & 2 & 3 & 4 & 5 & 6 & 7 & 8 & 9 & 10 & 11 & 12 & 13 & 14 & 15 & 16 \\
\hline 1 & & $A$ & $B$ & $B$ & $A$ & $B$ & $B$ & $A$ & $B$ & $A$ & $A$ & $A$ & $A$ & $A$ & $A$ & $A$ \\
\hline 2 & $B$ & & $B$ & $B$ & $B$ & $B$ & $B$ & $B$ & $B$ & $A$ & $A$ & $A$ & $B$ & $A$ & $A$ & $A$ \\
\hline 3 & $A$ & $B$ & & $B$ & $B$ & $B$ & $B$ & $B$ & $A$ & $B$ & $B$ & $B$ & $B$ & $B$ & $A$ & $A$ \\
\hline 4 & $B$ & $B$ & $B$ & & $B$ & $B$ & $B$ & $B$ & $B$ & $A$ & $A$ & $A$ & $A$ & $A$ & $A$ & $A$ \\
\hline 5 & $A$ & $B$ & $B$ & $B$ & & $B$ & $B$ & $B$ & $B$ & $B$ & $B$ & $A$ & $B$ & $B$ & $A$ & $A$ \\
\hline 6 & $B$ & $B$ & $B$ & $B$ & $B$ & & $B$ & $B$ & $B$ & $A$ & $A$ & $A$ & $A$ & $A$ & $A$ & $A$ \\
\hline 7 & $B$ & $B$ & $B$ & $B$ & $B$ & $B$ & & $B$ & $B$ & $A$ & $A$ & $A$ & $B$ & $A$ & $A$ & $A$ \\
\hline 8 & $A$ & $B$ & $B$ & $B$ & $B$ & $B$ & $B$ & & $A$ & $B$ & $B$ & $B$ & $B$ & $B$ & $A$ & $A$ \\
\hline 9 & $B$ & $B$ & $A$ & $B$ & $B$ & $B$ & $B$ & $A$ & & $A$ & $A$ & $A$ & $A$ & $A$ & $A$ & $A$ \\
\hline 10 & $A$ & $A$ & $B$ & $A$ & $B$ & $A$ & $A$ & $B$ & $A$ & & $B$ & $B$ & $B$ & $B$ & $A$ & $B$ \\
\hline 11 & $A$ & $A$ & $B$ & $A$ & $B$ & $A$ & $A$ & $B$ & $A$ & $B$ & & $B$ & $B$ & $B$ & $A$ & $B$ \\
\hline 12 & $A$ & $A$ & $B$ & $A$ & $A$ & $A$ & $A$ & $B$ & $A$ & $B$ & $B$ & & $B$ & $B$ & $B$ & $B$ \\
\hline 13 & $A$ & $B$ & $B$ & $A$ & $B$ & $A$ & $B$ & $B$ & $A$ & $B$ & $B$ & $B$ & & $B$ & $A$ & $B$ \\
\hline 14 & $A$ & $A$ & $B$ & $A$ & $B$ & $A$ & $A$ & $B$ & $A$ & $B$ & $B$ & $B$ & $B$ & & $A$ & $B$ \\
\hline 15 & $A$ & $A$ & $A$ & $A$ & $A$ & $A$ & $A$ & $A$ & $A$ & $A$ & $A$ & $B$ & $A$ & $A$ & & $B$ \\
\hline 16 & $A$ & $A$ & $A$ & $A$ & $A$ & $A$ & $A$ & $A$ & $A$ & $B$ & $B$ & $B$ & $B$ & $B$ & $B$ & \\
\hline
\end{tabular}


The treatments with hen manure source presented significant differences in their medium and high doses (150 and $\left.200 \mathrm{~N} \mathrm{~kg}^{-h^{-1}}\right)$, with respect to the pine nut cake and urea treatments for all doses. On the other hand, pine nut cake showed significant differences with bovine manure (50, 100 and $\left.200 \mathrm{~N} \mathrm{~kg} \cdot \mathrm{ha}^{-1}\right)$ and poultry manure in the

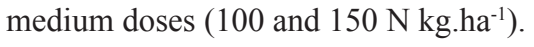

Finally, as shown in table 7, the urea treatment with medium dose $\left(150 \mathrm{~N} \mathrm{~kg} \cdot \mathrm{ha}^{-1}\right)$, was the one that presented a significant difference between treatments, except with pine nut cake at its highest dose $\left(200 \mathrm{~N} \mathrm{~kg} \cdot \mathrm{ha}^{-1}\right)$, so it was considered the source that favored the development of the cotton crop, based on the observed spectral response.

Reflectance levels. The greater vigor of the crop, in view of the chlorophyll indices evaluated, does not correspond to the maximum concentration of urea (200 N kg.ha-1) applied in this investigation (figure 4). Although it is true that there are no figures on recommended doses, many producers exceed this amount, which implies an excess of product that unnecessarily increases production costs, in addition to contributing to environmental problems of contamination and

\section{Simple Ratio Red}

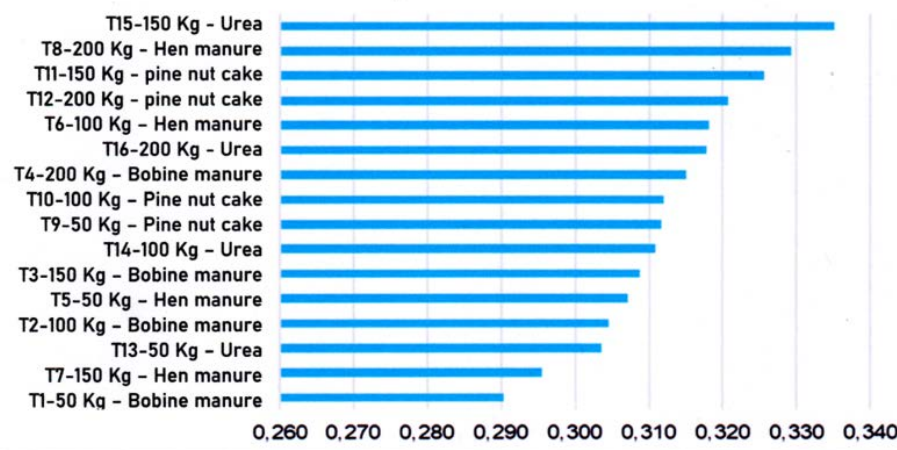

\section{Normalized Difference Red_Edge Index NDRE}

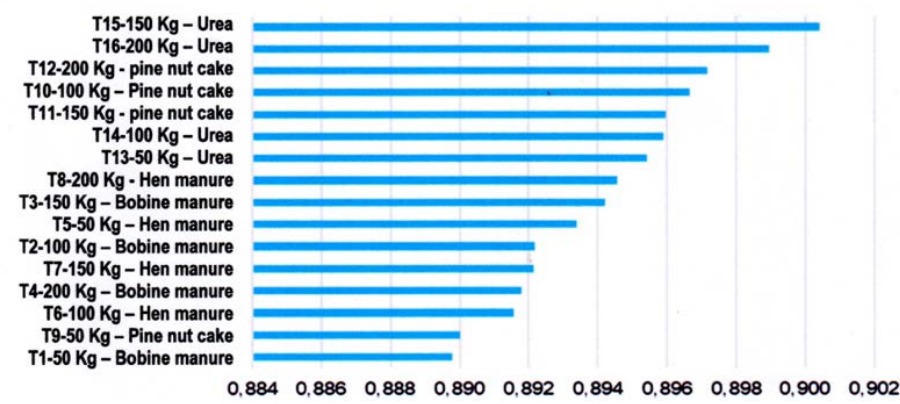

Figure 4. Reflectance levels of the cotton crop according to the applied treatment.

Likewise, it was observed that the plants treated with pine nut cake and hen manure show vigor and can become substitutes for urea. The plots with bovine manure presented the lowest vigor in the crop.

\section{Conclusions}

The unmanned aerial vehicle showed great efficiency for the application of the procedures used, forming a fundamental part in the application of technology in agriculture and production, thanks to its easy handling and the large amount of information it can generate.

The analyzed indices were able to visually show the differences in the vigor of the crop, depending on the various nitrogen fertilization treatments. Therefore, with the application of this technology, the application of fertilizers can be optimized, by selecting the best nitrogen source for the study conditions.

The GIS tool proved to be very useful in differentiating the areas of the crop with greater or lesser development of the plants based on the chlorophyll index, thus being able to take advantage of the information obtained to cover the needs of the areas with nutritional deficiency.

The application of the chlorophyll indices made it possible to determine the most effective nitrogenous sources in plants, with urea at a dose of $150 \mathrm{~N} \mathrm{~kg} \cdot \mathrm{ha}^{-1}$ being the source with the best spectral response for the four calculated indices.

The results of the research allow the recommendation of doses and nitrogenous sources that could imply improvements in crop production in economic and environmental terms in the study area.

\section{Literature cited}

ArcGIS. (2020). Conjunto de herramientas de Álgebra de mapas. https://bit. ly/30SDu5a.

Bartesaghi, C., Osmond, P., Peters, A. \& Matthias, I. (2018). Understanding land surface temperature differences of local climate zones based on airborne remote sensing data. Ieee Journal of Selected Topics in Applied Earth Observations and Remote Sensing, 11(8), 2724-2730. https://bit. ly/3dtBLWZ.

Burbano, C., y Peñaranda, G. (2020). Breve visión de los aspectos evolutivos de la agricultura de precisión como herramienta de gestión. Lumen Gentium, 4(1), 57-67. https://bit.ly/3cFg2v9.

Karydas, C., Latrou M., Kouretas, D., Patouna, A., Latrou G., Lazos, N., Gewehr, S., Tseni X., Tekos F., Zartaloudis, Z., Mainos, E. \& Mourelatos, S. (2020). Prediction of antioxidant activity of cherry fruits from UAS multispectral imagery using machine learning. Journal of Antioxidants, 9(2), 156. Disponible en: https://bit.ly/3r29L4O.

Kharuf-Gutierrez, S., Hernández-Santana, L., Orozco-Morales, R., Díaz, A., y Delgado Mora, I. (2018). Análisis de imágenes multiespectrales adquiridas con vehículos aéreos no tripulados. Ingeniería Electrónica Automática y Comunicaciones, 39(2), 79-91. https://bit.ly/3xoq3Gr.

Ledesma M., Rodríguez C., Ledesma, C., Bonansea, M., Pinotti, L. P., Scavuzzo, C. M., y Ferral, A. (2020). Análisis de la distribución temporal de la concentración de Clorofila-a en el embalse Río Tercero, Córdoba, Argentina. Ab Intus, 3(5), 83-87. https://bit.ly/30P6NWX.

Macías-Duarte, R., Grijalva-Contreras, R. L., Robles-Contreras, F., NúñezRamírez, F., Cárdenas-Salazar, V. A., \& Mendóza-Pérez, C. (2021). SPAD index, nitrates, and sorghum yield in response to nitrogen supply. Agronomía Mesoamericana, 32(1), 293-305. https://bit.ly/3DPU3O2.

Marín, J., Betancur, L., y Arguello, H. (2018). Modelo de muestreo comprimido multiespectral para radio cognitiva. Ingeniare. Revista chilena de Ingeniería, 26(2), 225-240. https://bit.ly/312WAx0.

Parrot Drone SAS. (2020). Manual, soporte y accesorio de uso de cámaras multiespectrales. Disponible en: https://bit.ly/3FyUwVc.

Pix4D SA. (2019). Pix4D Mapper. https://bit.ly/3nJgcrs.

Prando, A., Souza, T., de Oliveira, A., \& Zucareli, C. (2019). Produtividade, índice de vegetação e clorofila de trigo em resposta à inoculação com Azospirillum brasilense e adubação nitrogenada em cobertura. Cultura Agronômica, 28(3), 329-342. https://bit.ly/3CFDSBq.

Xu, M., Liu, R., Chen, J., Liu, Y., Shang, R., Ju, W., Wu, Ch. \& Huang, W. (2019). Retrieving leaf chlorophyll content using a matrix-based vegetation index combination approach. Remote Sensing of Environment, 224, 60-73. https://bit.ly/3pME11F.

Zhou, X., Huang, W., Kong, W., Ye, H., Dong, Y. \& Casa, R. (2017). Assessment of leaf carotenoids content with a new carotenoid index: Development and validation on experimental and model data. International journal of Applied Earth Observation and Geoinformation, 57(5), 24-35. https://bit. ly/3Eux1wf.

Zhou, X., Huang, W., Zhang, J., Kong, W., Casa, R., \& Huang, Y. (2019). A novel combined spectral index for estimating the ratio of carotenoid to chlorophyll content to monitor crop physiological and phenological status. International Journal of Applied Earth Observation and Geoinformation, 76(3), 128-142. https://bit.ly/3IptC46. 